REPORTS OF MORPHOLOGY
$\begin{gathered}\text { Official Journal of the Scientific Society of Anatomists, } \\ \text { Histologists, Embryologists and Topographic Anatomists } \\ \text { of Ukraine } \\ \text { journal homepage: https://morphology-journal.com }\end{gathered}$

\title{
Characteristics of nervous tissue after modeling of focal cerebral ischemia in rats at different periods of reperfusion
}

Savchuk O.I., Skibo G.G.

Bohomoletz Institute of Physiology National Academy of Sciences of Ukraine, Kyiv, Ukraine

\section{ARTICLE INFO}

Received: 20 July, 2018

Accepted: 23 August, 2018

UDC: $591.481 .1: 616-005.4: 612.825$

\section{CORRESPONDING AUTHOR}

e-mail: floweringbowl@ukr.net Savchuk O.I.
The stroke-causing problems are extremely important in Ukraine. This makes a heavy burden not only on the health care system, but also on the whole society as a whole. That's why we've studied structural and ultrastructural changes of cortical neurons and striatum of the brain and the development of delayed death of nerve cells after the modeling of the middle cerebral artery occlusion (MCAO) and post ischemic period in rats. We've analyzed the data at different terms after modeling of MCAO. The purpose of the study was to investigate the changes in the nervous tissue in the modeling of focal cerebral ischemia by monofilament occlusion of MCAO in rats at different periods of reperfusion. The statistical processing of primary digital experimental data was carried out using the software Statistica 6.0. It was confirmed that the 60-minute occlusion of the MCAO is an adequate model of focal ischemic brain damage in rats. Changes of locomotor activity and a tactile sensitivity were determined in rats after occlusion and after reperfusion during the post-period period. It was found that in the experimental group with a reperfusion period of 72 hours, a clear increase of the volume of the ischemic area of the brain, accompanied by significant neurological deficiency, was observed. Reduced research activity of the rats was revealed, which was shown in the decrease of the number of squares they crossed, the number of racks, the increase of acts of grooming and the duration of acts of frizings. Following ischemic brain damage, there was also a disbalance of somato-sensory functions, as evidenced by an increase in the time during which the animal took a test stimulus ("Sticky tape") from both the anterior paws when tested for tactile sensitivity (adhesive removal test). An electron microscopic study of the cortex showed that dark wrinkled neurons and enlightened swollen neurons were observed at 72 hours of post-occlusion period, indicating different ways of death of these cells. Changes in striatum were similar to changes in the cortex, which progressed with an increase in the post-occlusion period. The protocol of the serial evaluation of neurological disorders used after MCAO modeling allowed detecting long-term stable functional disorders in laboratory rats. The obtained data indicate significant changes in the structure of the cortex and striatum in the post-ischemic period and the progressive nature of these changes.

Key words: ischemic stroke, focal cerebral ischemia, monofilament occlusion.

\section{Introduction}

Ischemic stroke (IS) is one of the most important causes of morbidity, disability and mortality in developed countries.

According to indicators of morbidity and mortality caused by stroke Ukraine occupies one of the first places in Europe. Every year from 100 to 110 thousand Ukrainians first get ill with cerebral stroke [5]. Every third stroke affects people of working age. From 40 to 43 thousand inhabitants die after stroke in Ukraine annually. According to the World Health Organization (WHO), stroke is the second only among world death factors, and the third is in developed countries and is a major factor in disabling the population $[3,23]$.

Modeling of ischemic brain damage is an indispensable step for approbation of treatment methods for patients with IS. The models of IS are the basis for determining the mechanisms of cell death in neuronal repair in vivo.

The disclosure of the pathophysiological mechanisms underlying the cell death in the area of brain infarction is a 
prerequisite for the development of new methods and therapeutic methods for IS.

The aim of the study was to analyze neural tissue changes after the modeling of focal cerebral ischemia by monofilament occlusion of MCA in rats at different periods of reperfusion and behavioral responses.

\section{Materials and methods}

Experimental studies were performed on 63 males of the Wistar line with body weight $280-320 \mathrm{~g}$ in age from 4 to 6 months.

Animals received from the vivarium of Bohomoletz Institute of Physiology National Academy of Sciences of Ukraine, where they were kept on a standard diet and in general were in similar conditions. All experiments were conducted in accordance with the "Rules for the implementation of works using experimental animals", approved by the Ministry of Health of Ukraine. Experimental procedures were carried out in the cytology department of Bohomoletz Institute of Physiology in the first half of the day, which coincided with the circadian rhythms of animals.

Animals were divided into 3 experimental groups ("Sham-operated" - an operating control in which all surgical manipulations were performed, except for the introduction of monofilament $(n=21)$, animals of the two following groups were modeled focal cerebral ischemia by monofilament occlusion of the middle cerebral artery by the method of J. Koizumi et al. (1986) using monofilaments with a silicone coating: "Short-term MCAO" - lasting 2 minutes $(n=21)$, "Long-term MCAO" - lasting 60 minutes $(n=21)[8,17,18]$.

To assess the presence of ischemic brain damage before the ischemia was simulated, and after 6, 24 and 72 hours of reperfusion, an "open field" test was performed that evaluated locomotor activity and a tactile sensitivity test $[2,13,21]$.

Sticky tape test is one of the most sensitive tests for identifying sensory disorders in rats with OCMA [9, 15]. For this, the animal was removed from the cage and labeled with a $3 \times 1 \mathrm{~cm}$ Leofix adhesive tape on the distal part of the front paw, deprived of wool, in a circle of $360^{\circ}$, so that both ends of the tape protruded and glued together, and the front paw protruded somewhat forward of the formed cuffs Immediately after the adhesion of the tape, the animal was placed back into the cage and began observation. The rats use their teeth and, to a lesser extent, the opposite limb to remove the tape. Before the start of the observation, two timers were triggered: one timer was switched on constantly, and the other one - during the attempts of the animal to remove the tape. Each attempt lasted 30 seconds. The desired ratio is the number of seconds the animal responds to the stimulus, divided by 30 seconds. This test was repeated with an opposite limb. Each session consisted of 5 attempts at each end. Of the 5 attempts, two best results were chosen. After each test, the tape was removed using warm water and soap.
The final result was expressed in a formula: $x=[(x 1+x 2) / 30)]-2 /[(y 1+y 2) / 30)]-2$

where $x$ - is the end result, $x 1$ and $x 2$ - are the number of seconds spent by the animal to remove the tape from the affected (left) extremity in the best attempts; in 1 and 2 - the number of seconds spent by the animal on removing the tape from the intact (right) limb, 30 - duration of the attempt (30s), 2 - two attempts with the best result.

When properly executed, this test clearly reflects the focal nature of the damage, demonstrating the pronounced difference in the score of the affected and intact limbs throughout the observation time.

The improved experimental model of ischemic stroke with the help of monofilament occlusion of the middle cerebral artery in rats allowed to reproduce the focal point of focal ischemic brain damage mainly in the cortex and striped body of rats, to a lesser extent, in adjacent brain structures, which was accompanied by the emergence of a stable and long-term neurological deficiency in the experimental animals.

To determine the ischemic volume, we calculated the area of the infarct area and multiplied it by the thickness of the sections (Fig. 1).

To determine the size of the cerebral infarction, in vivo experiments, we chose a commonly used method that allows the macroscopic level to separate the damaged (necrotized) region of the brain from the brain tissue that retained viability and was substantiated by the staining of TTC brain sections. The slices of the brain were placed in a $2 \%$ solution of TTC, which paints a viable tissue in a bright red color. Incubation sections were performed for 15 minutes at $37^{\circ} \mathrm{C}$.

According to the literature, on the 3rd day after MCAO there is a clearly defined zone of ischemic injury, with the area of perifocal edema less pronounced than on 1st - 2nd day $[1,6,16,22]$. In these studies, we conducted a

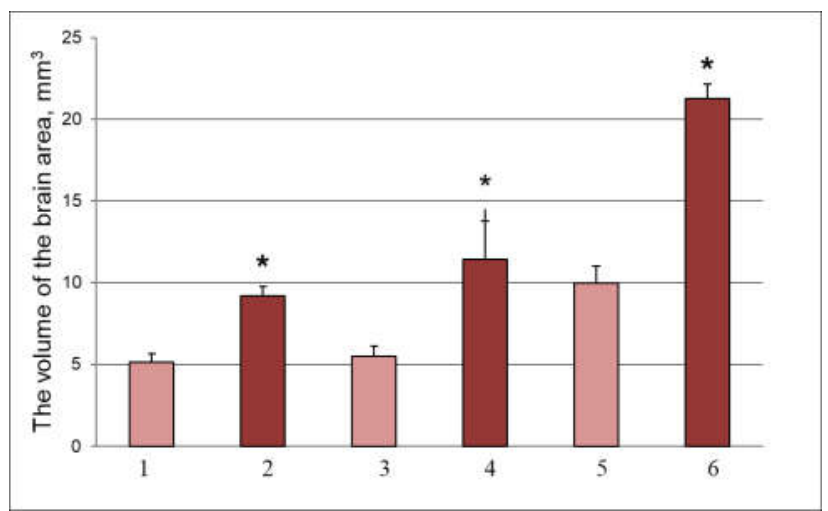

Fig. 1. Volume of the area $\left(\mathrm{mm}^{3}\right)$ of ischemic damage in animals at different periods of reperfusion after MCAO. 1 - 6 hour reperfusion group of short-term MCAO; 2 - 6 hour reperfusion of long-term MCAO; 3 - 24 hour reperfusion group of short-term MCAO; 4 - 24 hour reperfusion group of long-term MCAO; 5 - 72 hour reperfusion of short-term MCAO; 6 - 72 hour reperfusion group of long-term MCAO; ${ }^{*}-p<0.05$. 
morphometric evaluation of lesions within 6 hours, 24 hours and 72 hours from the time of occlusion.

It is known that after ischemic brain damage there are changes of neurological functions in experimental animals $[3,10]$. Therefore, in addition to the study of morphological changes occurring in the ischemic brain, we determined locomotor activity and conducted a test for tactile sensitivity in rats before occlusion and after reperfusion during the post-ischemic period. We conducted behavioral reactions in animals of different groups in 6, 24 and 72 hours after the modeling of focal ischemia. The main indicators were evaluated: motor activity, research activity and degree of anxiety, which was evaluated by grooming (all varieties of this reaction, which manifested themselves in licking and scratching), frizings (fading).

Another indicator, which was analyzed during the "open field" test, was the measurement of the number of racks (vertical motor activity) that demonstrated the research activity.

Structural characteristics of cortical nerve cells and striatum of the brain in the post-lateral period were investigated using light and electron microscopy methods.

Analysis and statistical processing of the results were carried out using the following software: ImageJ, Exel, Origin 8.0, SPSS ver., 20.0.

\section{Results}

In the sham-operated animals, histological damage to the brain was not observed.

In the group of animals of short-term occlusion of MCA after $6,24,72$ hours the amount of damage was $5.110 \pm 1.250$ $\mathrm{mm}^{3} ; 5.520 \pm 1.470 \mathrm{~mm}^{3} ; 10.01 \pm 2.340 \mathrm{~mm}^{3}$, respectively, and in animals of the group of long-term occlusion of MCA in the similar terms of the experiment $-9.180 \pm 1.430 \mathrm{~mm}^{3}$, $11.47 \pm 5.41 \mathrm{~mm}^{3}, 21.27 \pm 2.07 \mathrm{~mm}^{3},(p<0.05)$.

It was found that in the experimental group with a reperfusion period of 72 hours, a clear increase in the volume of the ischemia of the brain. This indicates that the process of damaging the brain is dynamic with a gradual increase in the area of damage with an increase in the period of reperfusion.

6 hours after the carotid occlusion of the carotid artery in rats there was a weakened locomotor activity, which gradually increased with the duration of the post-ischemic period; single spontaneous movements were rotational.

A group of pseudo-operated animals showed a high percentage of research activity and averaged $86 \%$ of the total number of racks. Rats with ischemic brain damage, in the first day after occlusion, this percentage was significantly lower $(19 \%)$ than in control animals and gradually decreased during the post occlusive period.

After the operation, all animals had a reduction in research activity, which was manifested in the reduction of the number of squares they crossed (Table 1), the number of racks, the increase in the acts of grooming and the duration of acts of frizings (Table 2).
Table 1. Counting the number of squares $(\mathrm{N})$, crossed by the rats when testing locomotor activity ("open field" test): in the control group (Pseudo-operated animals) and after 6, 24 and 72 hours after ischemia. $\left.{ }^{*}-p<0.01\right)$.

\begin{tabular}{|c|c|c|c|c|}
\hline $\begin{array}{c}\text { Time of } \\
\text { reperfusion }\end{array}$ & $\mathrm{N}$ & $\begin{array}{c}\text { Pseudo-operated } \\
\text { animals }\end{array}$ & $\begin{array}{c}\text { Short-term } \\
\text { MCAO }\end{array}$ & $\begin{array}{c}\text { Long-term } \\
\text { MCAO }\end{array}$ \\
\hline 6 hours & 7 & $41.20 \pm 6.94$ & $22.60 \pm 1.20^{*}$ & $16.01 \pm 1.73^{*}$ \\
\hline 24 hours & 7 & $43.80 \pm 1.32$ & $23.50 \pm 1.05^{*}$ & $19.80 \pm 2.85^{*}$ \\
\hline 72 hours & 7 & $45.20 \pm 1.90$ & $28.20 \pm 3.44^{*}$ & $24.40 \pm 1.86^{*}$ \\
\hline
\end{tabular}

Table 2. Indicator of increased level of stress and freezing by the open field test: in the control group (Pseudo-operated animals), and after 6, 24 and 72 hours after ischemia with an occlusion duration of 2 minutes (Short-term MCAO) and 60 minutes (Longterm MCAO) expressed in seconds $\left({ }^{*}-p<0.01\right)$.

\begin{tabular}{|c|c|c|c|}
\hline $\begin{array}{c}\text { Time of } \\
\text { reperfusion }\end{array}$ & $\begin{array}{c}\text { Pseudo-operated } \\
\text { animals }\end{array}$ & $\begin{array}{c}\text { Short-term } \\
\text { MCAO }\end{array}$ & $\begin{array}{c}\text { Long-term } \\
\text { MCAO }\end{array}$ \\
\hline 6 hours & $5.001 \pm 2.110$ & $9.001 \pm 1.490^{*}$ & $18.80 \pm 4.49^{*}$ \\
\hline 24 hours & $6.000 \pm 2.490$ & $18.00 \pm 4.81^{*}$ & $28.60 \pm 5.79^{*}$ \\
\hline 72 hours & $7.810 \pm 2.040$ & $19.80 \pm 3.49^{*}$ & $31.20 \pm 5.30^{*}$ \\
\hline
\end{tabular}

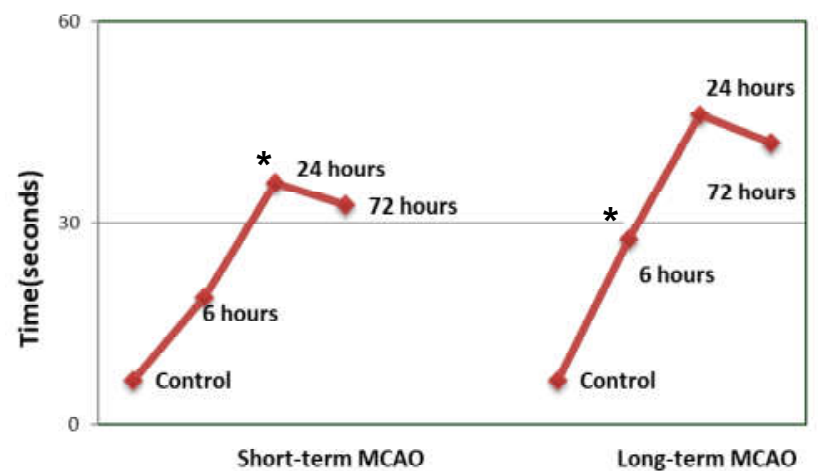

Fig. 2. Duration of rats removing the test stimulus when tested for adhesion removal to ischemia (Control) and after 6, 24 and 72 hours after ischemia. ${ }^{*}-p<0.01$.

There was also a violation of somatosensory functions following an ischemic injury in the brain, as evidenced by an increase in the time during which the animal took a test stimulus ("Sticks") from both front paws when tested for tactile sensitivity (adhesive removal test) (Fig. 2).

In a microscopic study, it was found that the zone of ischemic lesion anatomically covers areas of the somatosensory (parietal region) and, in part, the motor cortex (the frontal and prefrontal areas), the corpus callosum, the lateral and, partially, the medial parts of the striped body, and reaches the wall of the right side Ventricle, which corresponds to the basin of the blood supply of the right MCA.

In the cortex of the contralateral hemisphere (control) we observed the normal structure of the neuropile, the synapses had clearly defined presynaptic vesicles, synaptic cleft and postsynaptic density (Fig. 3A).

Microglial cells, microglia and astrocytes, were the first to respond to ischemic injury. Already after 6 hours we observed edema of astrocyte processes (Fig. 3B).

With the increase of the post-occlusion period, destructive 

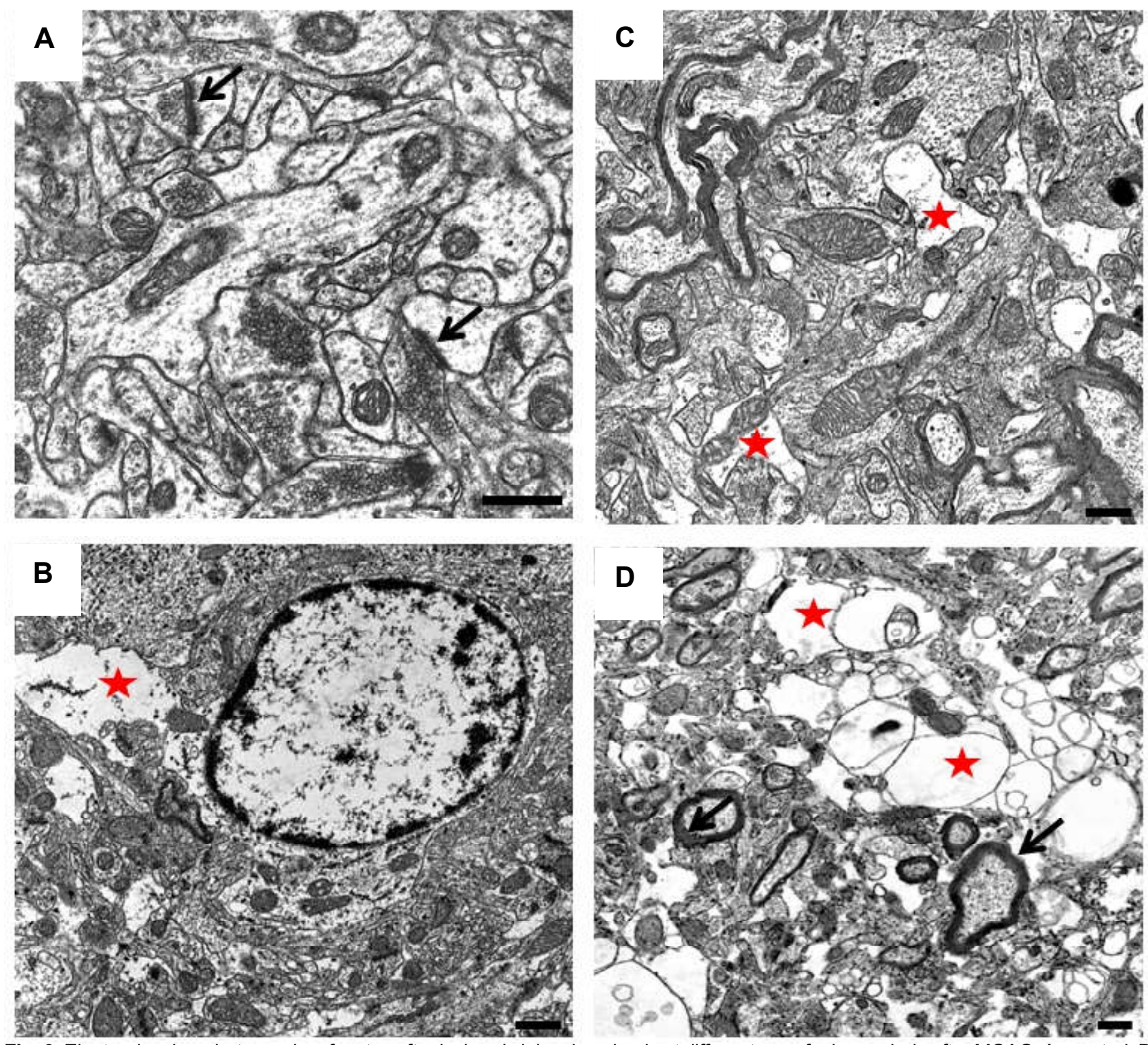

Fig. 3. Electronic microphotography of cortex after ischemic injury in animals at different reperfusion periods after MCAO: A- control; $B$ - after 6 hours the structural changes of the neuropile are expressed in a vague way; C - after 24 hours there are more pronounced destructive changes, swelling of not only appendages, but also somas of astrocytes (indicated by a star); D - after 72 hours there were clear signs of degenerative changes of neuropile, manifested in the devastation and edema of dendrites and astrocytes (indicated by a star), pathological changes in myelin fibers (indicated by an arrow). The large line A, B, D - 0.4 microns, C - 0.8 microns.

changes in the cortex were increasing. After 24 hours we observed a swelling of not only astrocyte processes, but also of astrocytes (indicated by an asterisk, Fig. 3C).

An electron microscopic study of the cortex showed that 72 hours of post-occlusion period were observed as dark wrinkled neurons and enlightened swollen, indicating different ways of death of these cells. At this period of reperfusion, we showed clear signs of degenerative neuropile changes, manifested in the devastation and edema of dendrites and astrocytes (indicated by asterisks), pathological changes in myelin fibers (indicated by an arrow, Fig. 3D).

In the group of animals with ischemia for 72 hours post- occlusion period, both necrotic and apoptotic altered neurons were observed, neuropile of the cortex was strongly vacuated.

In the microvessels of the cortex there was a progressive, perivascular edema of the structures over time, of which the blood-brain barrier, mainly astrocytic processes, is formed.

Changes in striatum were similar to changes in the cortex, which progressed with an increase in the post-occlusion period. On the electronogram of the striatum site, we observed bundles of the myelin sheath, the destruction of microtubules in dendrites, and the presence of degenerative changes in synaptic terminals.

In the striatum of the contralateral hemisphere (control), the neuron bodies had a large, light rounded nucleus with 

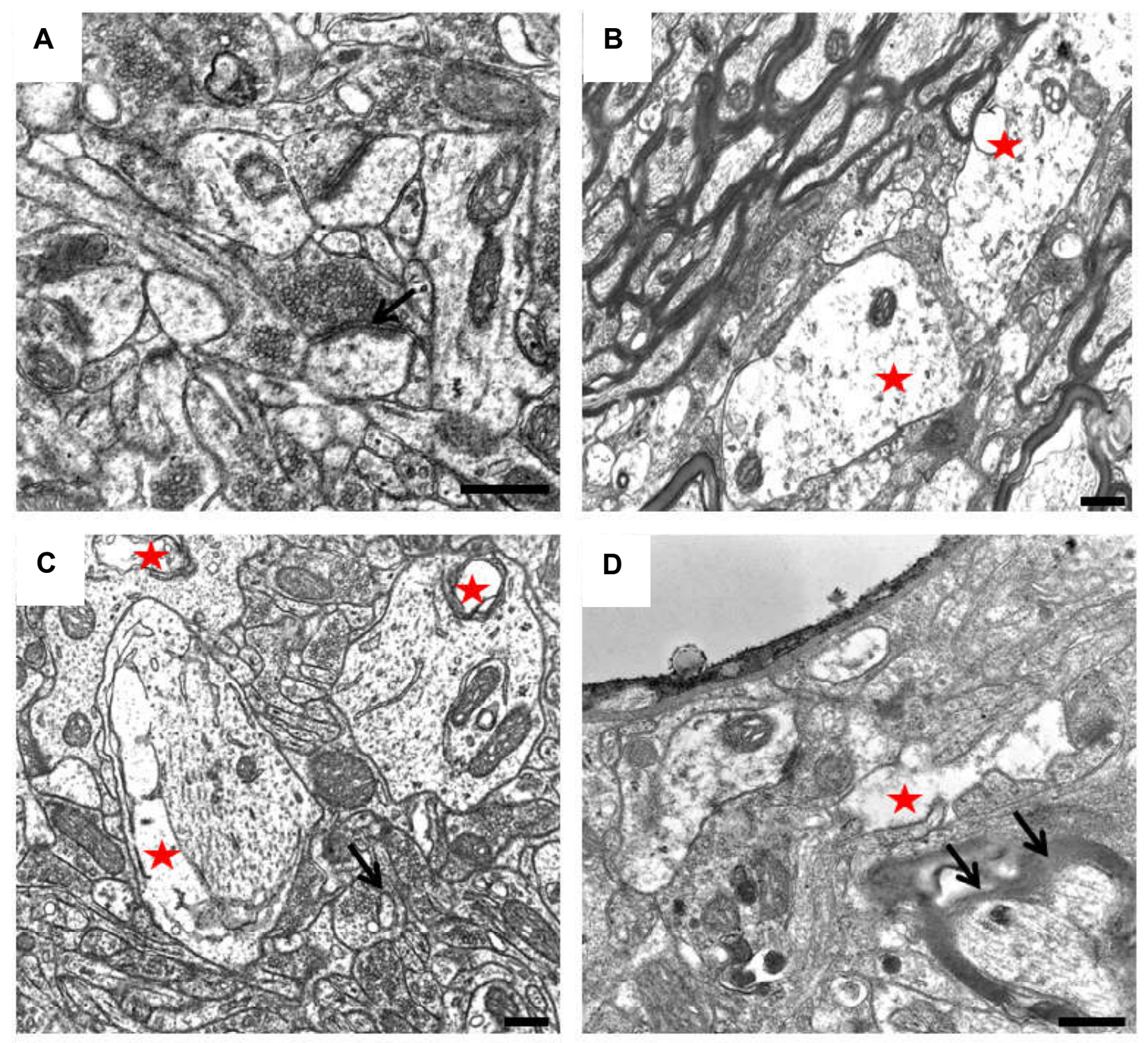

Fig. 4. Electron micrographs of striatum after ischemic injury in animals at different periods of reperfusion after MCAO: A- control; B after 6 hours there are minor changes of neuropile, which are manifested in the enlightenment of astrocyte processes; $C$ - after 24 hours destructive changes became more pronounced, destruction of mitochondria (indicated by a star), violation of the structure of synapses (indicated by an arrow); D - after 72 hours, swelling of the sprouts (indicated by a star), myelin bundle (indicated by the arrows) is observed. The large ruler is 0.4 microns.

well-differentiated one or two nucleoli and a narrow strip of slightly darker cytoplasm around the nucleus. In the control group, synapses can be visualized with well-defined presynaptic vesicles, synaptic cleft and postsynaptic density (Fig. 4A).

MCAO after 6 hours of reperfusion led to minor structural changes in neuropile, which manifested in enlightened astrocyte processes (Fig. 4B).

After 24 hours destructive changes became more pronounced, destruction of mitochondria (indicated by asterisks), destruction of the structure of synapses (indicated by an arrow, figure $4 \mathrm{C}$ ).

The most striking were changes in striatum for 72 hours after occlusion of the carotid artery. Significant destructive changes in neuropile are observed, edema of the processes (indicated by an asterisk), myelin bundle (indicated by the arrowheads, Fig. 4D).

\section{Discussion}

A detailed assessment of neurological functions and behavioral reactions may require a large set of tests, each of which meets a certain aspect of animal behavior. The optimal set of tests should meet the requirements and objectives of a particular experiment and be sensitive to the type and severity of the deficit predicted after simulation of neurological damage. Since the effects of ischemic stroke 
in humans are mainly sensory, motor and cognitive impairments, experimental post- MCAO tests in animals should be aimed at quantifying these violations and independent of compensatory behavior, due to repeated repetition of the procedure and training $[7,20]$.

Behavioral testing also allows to monitor changes in the neurological functions under the influence of new regenerative technologies (cell and gene therapy, growth factors, etc.). The need for statistically significant results requires the availability of an experimental model that can reproduce the mechanisms of the IS observed in humans [14].

In the majority of cases, as a result of MCAO, the centers of ischemic damage are formed in large sizes and the volume of the area of the damage in the acute period of the stroke (24 hours) is used as the final value for assessing the effectiveness of therapy $[6,13]$. However, according to some researchers, the area of the damage after a 60-minute MCAO gradually increases for 6 weeks to its stabilization [13]. Expert recommendations and protocols of preclinical studies indicate the need to evaluate the effectiveness of new treatment methods IS based on behavioral responses and functional changes in experimental animals for a long observation time (11 months) [12].

The one-way MCAO leads to contralateral neurological

\section{References}

[1] Apple, D. M., Solano-Fonseca, R., \& Kokovay, E. (2017). Neurogenesis in the aging brain. Biochem Pharmacol, 141, 77-85, doi:10.1016/j.bcp.2017.06.116.

[2] Belayev, L., Endres, M., \& Prinz, V. (2010). Focal cerebral ischemia in the mouse and rat using the intraluminal suturefilament model. Neuromethods. Ed. by Ulrich Dirnagl. - Berlin: Humana Press, 286.

[3] Benjamin, E. J., Blaha, M. J., Chiuve, S. E., Cushman, M., Das, S. R., Deo R, de Ferranti. ... Muntner, P. (2017). American Heart Association Statistics Committee and Stroke Statistics Subcommittee. Heart Disease and Stroke Statistics. Update: A Report From the American Heart Association. Circulation, 135(10), 146-603, doi: 10.1161/CIR.0000000000000485.

[4] Freret, T. (2009). Improvements of the Stroke Model Guidelines. Animal body weight and long-term functional concerns. $J$. Exp. Stroke Transl. Med., 2(2), 28-31, doi: 10.1038/ jcbfm.2012.185.

[5] Gandzjuk, V. A. (2014). The dynamics of morbidity and prevalence of circulatory system diseases among the population of Ukraine at the present stage: national and regional aspects. Bulletin of Social Hygiene and Health Care Organizations of Ukraine, 60(2), 74-78.

[6] Jander, S., Schroeter, M., Saleh, A. doi:10.1002/nbm.881 (2007). Imaging inflammation in acute brain ischemia. Stroke, 38(2), 642-645.

[7] Kojima, T., Hirota, Y., Ema, M., Takahashi, S., Miyoshi, I., Okano, H., \& Sawamoto, K. (2010). Subventricular zone-derived neural progenitor cells migrate along a blood vessel scaffold toward the post-stroke striatum. Stem Cells, 28(3), 545-548, doi:10.1002/stem.306.

[8] Koizumi, J., Yoshid, Y., Nakazama, T., \& Genju, O. (1986). Experimental studies of ischemic brain edema:1. A new experimental model of cerebral embolism in rats in which deficits, which manifests itself primarily asymmetry of sensory and motor functions $[4,7,12,19]$.

Thus, the data obtained indicate significant changes in the structure of cerebral cortex and striatum in the postischemic period and the progressive nature of these changes.

The obtained results will be used in the future to study the participation of proteasome proteolysis and its role in the processes of ischemic brain damage, as well as to create opportunities for its influence on the prevention and treatment of cerebral diseases in general and ischemic stroke in particular.

\section{Conclusions}

1. It is confirmed that 60 -minute occlusion of MCA is an adequate model of focal ischemic brain damage in rats.

2. The protocol of serial evaluation of neurological disorders that we've proposed after the modeling of MCAO allowed to detect long-term stable functional disorders in laboratory rats.

3. It was shown that at transient occlusion of the middle cerebral artery, there were structural and ultrastructural changes in the zone of damage to the brain tissues of rats and had a progressive nature with an increase in the postocclusion period.

recirculation can be introduced in the ischemic area. Stroke J., 8, 1-8.

[9] Komotar, R. J., Kim, G. H., \& Sughrue, M. E. (2007). Neurologic assessment of somatosensory dysfunction following an experimental rodent model of cerebral ischemia. Nature Protocols, 2(10), 2345-2347, doi:10.1038/nprot.2007.359.

[10] Lindner, M. D., Gribkoff, V. K., \& Donlan, N. A. (2003). Longlasting functional disabilities in middle-aged rats with small cerebral infarcts. The Journal of Neuroscience, 23(34), 10913-10922.

[11] Meloni, B. P., Zhu, H., \& Knuckey, N. W. (2006). Is magnesium neuroprotective following global and focal cerebral ischaemia? A review of published studies. Magnes Res., 19(2), 123-137.

[12] Modo, M. (2009). Long-term survival and serial assessment of stroke damage and recovery-practical and methodological considerations. J. Exp. Stroke Transl. Med., 22(2), 52-68, doi:10.6030/1939-067X-2.2.52.

[13] Modo, M., Stroemer, R. P., \& Tang, E. (2000). Neurological sequelae and long-term behavioural assessment of rats with transient middle cerebral artery occlusion. Journal of Neuroscience Methods, 194, 99-109, doi: 10.1016/S01650270(00)00329-0.

[14] Schaar, K. L. (2010). Functional assessments in the rodent stroke. Experimental \& Translational Stroke Medicine, 2(13), 1-11, doi: 10.1186/2040-7378-2-13.

[15] Schallert, T., Woodlee, M. T., \& Fleming, S. M. (2002). Disentangling multiple types of recovery from brain injury. Pharmacology of Cerebral Ischemia, 201-217.

[16] Skibo, G. G., Kovalenko, T. M., Osadchenko, I. O., Tsupikov, O. M., \& Pivneva, T. A. (2006). Structural changes in the hippocampus in experimental brain ischemia. Ukrainian Neurological Journal, 1, 86-92.

[17] Tamura, A., Graham, D.I., McCulloch, J., \& Teasdale, G. M. 
(1981). Focal cerebral ischemia in the rat: 1. Description of technique and early neuropathological consequences following middle cerebral artery occlusion. J. Cereb. Blood Flow Metab., 1, 53-60.

[18] Traystman, R. (2003). Animal models of focal and global cerebral ischemia. ILAR Journal., 44(2), 85-95.

[19] Tsimbalyuk, V. I., \& Yarmolyuk, Ye. S. (2012). Modified model of experimental ischemic stroke in rats using monophlates with silicone coating. Ukrainian Neurological Journal, 4, 97105.

[20] Tsupikov, O., Kirik, V., Smozhanik, E., Rybachuk, O., Butenko, G., Pivneva, T., \& Skibo, G. (2014). Long-term fate of grafted hippocampal neural progenitor cells following ischemic injury. J. Neurosci. Res., 92(8), 964-974.

[21] Tsupikov, O., Kirik, V., Yatsenko, K., Butenko, G., \& Skibo, G. (2017). Influence of transplanted neural progenitors on proliferation of hippocampal cells after ischemic brain damage. ScienceRise. Medical Science, 14(6), 32-36.

[22] Zhang, F., Liu, C. L., \& Hu, B. R. (2006). Irreversible aggregation of protein synthesis machinery after focal brain ischemia. J. Neurochem, 98, 102-112.

[23] Zozulya, I. S. (2011). Epidemiology of cerebrovascular diseases in Ukraine. Ukrainian Medical Journal, 85(5), 3841.

\section{ХАРАКТЕРИСТИКА НЕРВОВОЇ ТКАНИНИ ПРИ МОДЕЛЮВАННІ ФОКАЛЬНОЇ ЦЕРЕБРАЛЬНОЇ ІШЕМІЇ У ЩУРІВ У РІЗНІ ПЕРІОДИ РЕПЕРФУЗІї \\ Савчук О.І., Скибо Г.Г.}

Проблеми, які спричиняє інсульт, є надзвичайно актуальними в Україні, тому нами були вивчені структурні та ультраструктурні зміни нейронів кори та стріатума головного мозку при моделюванні порушення кровопостачання в різні строки оклюзії середньої мозкової артерії (ОСМА) та постішемічного періоду у щурів. Мета дослідження - аналіз змін нервової тканини при моделюванні фокальної церебральної ішемії шляхом монофріламентної оклюзії СмА у шурів у різні періоди реперфузії та зміни поведінкових реакцій. Статистичну обробку первинних цифрових експериментальних даних здійснювали за допомогою програмного забезпечення Statistica 6.0. Підтверджено, що 60-хвилинна ОСмА є адекватною моделлю фоккального ішемічного пошкодження головного мозку щурів. Використовуючи поведінкові тести, виявлено зміни локомоторної активності та тактильної чутливості у щурів після оклюзії та після реперфузії протягом постішемічного періоду. Виявлено, що в дослідній групі з періодом реперфузії 72 години спостерігається чітке збільшення об'єму ішемізованої ділянки мозку, що супроводжується значним неврологічним дефіцитом. Виявлено зниження дослідницької активності щурів, що проявлялось в зменшенні кількості квадратів, які вони перетинали, кількості стійок, збільшенні актів грумінгу та тривалості актів фризінгу. Після ішемічного ушкодження мозку спостерігалось також порушення сомато-сенсорних функцій, про що свідчило збільшення часу, протягом якого тварина знімала тестовий стимул ("липучку") з обох передніх лап при тестуванні на тактильну чутливість (adhesive removal test). Електронно-мікроскопічне дослідження кори показало, що на 72 годину постоклюзійного періоду спостерігалися як темні зморщені нейрони, так і просвітлені набухлі, що свідчило про різні шляхи загибелі цих клітин. Зміни в стріатумі були аналогічними змінам в корі, які прогресували зі збільшенням постоклюзійного періоду. Запропонований нами протокол серійної оцінки неврологічних порушень при моделюванні осмА дозволив виявити довготривалі стійкі функціональні порушення у лабораторних щурів. Отримані дані свідчать про суттєві зміни структури кори та стріатума в постішемічному періоді і про прогресуючий характер цих змін.

Ключові слова: ішемічний інсульт, фокальна церебральна ішемія, монофіламентна оклюзія.

\section{ХАРАКТЕРИСТИКА НЕРВНОЙ ТКАНИ ПРИ МОДЕЛИРОВАНИИ ФОКАЛЬНОЙ ЦЕРЕБРАЛЬНОЙ ИШЕМИИ У КРЫС В РАЗНЫЕ ПЕРИОДЫ РЕПЕРФУЗИИ \\ Савчук Е.И., Скибо Г.Г.}

Проблемы, которые вызывает инсульт, являются чрезвычайно актуальными в Украине, поэтому нами были изучены структурные и ультраструктурные изменения нейронов коры и стриатума мозга при моделировании нарушения кровоснабжения в разные сроки окклюзии средней мозговой артерии (ОСМА) и в постишемическом периоде у крыс. Цель исследования - анализ изменений нервной ткани при моделировании фокальной церебральной ишемии путем монофиламентной окклюзии СМА у крыс в разные периоды реперфузии и изменении поведенческих реакций. Статистическую обработку первичных цифровых экспериментальных данных осуществляли с помощью программного обеспечения Statistica 6.0. Подтверждено, что 60-минутная окклюзия СМА является адекватной моделью фокального ишемического повреждения головного мозга крыс. Используя поведенческие тесты, выявлены изменения локомоторной активности и тактильной чувствительности у крыс после окклюзии и после реперфузии в течение постишемического периода. Выявлено, что в экспериментальной группе с периодом реперфузии 72 часа наблюдается четкое увеличение объема ишемизированного участка мозга, сопровождающегося значительным неврологическим дефицитом. Выявлено снижение исследовательской активности крыс, что проявлялось в уменьшении количества квадратов, которые они пересекали, количества стоек, увеличении актов груминга и продолжительности актов фризинга. После ишемического повреждения мозга наблюдалось также нарушение сомато-сенсорных фрункций, о чем свидетельствовало увеличение времени, в течение которого животное снимало тестовый стимул ("липучку") с обеих передних лап при тестировании на тактильную чувствительность (adhesive removal test). Электронно-микроскопическое исследование коры показало, что на 72 часу постокклюзионного периода наблюдались как темные сморщенные нейроны, так и просветленные набухшие, что свидетельствовало о различных путях гибели этих клеток. Изменения в стриатуме были аналогичными изменениям в коре, которые прогрессировали $c$ увеличением постокклюзионного периода. Предложенный нами протокол серийной оценки неврологических нарушений при моделировании ОСМА позволил выявить долговременные устойчивые фрункциональные нарушения у лабораторных крыс. Полученные данные свидетельствуют о существенных изменениях структуры коры и стриатума в постишемическом периоде и о прогрессирующем характере этих изменений.

Ключевые слова: ишемический инсульт, фокальная церебральная ишемия, монофиламентная окклюзия. 